\section{Sinoatrial Arrest: An Interaction between Phenytoin and Lignocaine}

\section{ROBERT A. WOOD}

British Medical fournal, 1971, 1, 645

Phenytoin, which does not impair atrioventricular conduction (Helfant, Scherlag, and Damato, 1967), is widely used to suppress ventricular extrasystoles or ventricular tachycardia resulting from acute myocardial infarction when there is associated or threatened atrioventricular block, or when other antiarrhythmic drugs have been unsuccessful. The case described below illustrates a serious side effect of phenytoin therapy occurring at ordinary dosage level in a patient who had received lignocaine.

\section{Case Report}

A 57-year-old man without a previous history of ischaemic heart disease was admitted to Aberdeen Royal Infirmary within half an hour of the onset of severe central chest pain. Pulse rate was $45 /$ minute and blood pressure $90 / 60 \mathrm{~mm} \mathrm{Hg}$, but the extremities were well perfused. An electrocardiogram showed grade 1 heart block, with a P-R interval of 0.26 second, and developing changes of transmural inferior infarction. After atropine sulphate $1 \mathrm{mg}$ had been injected subcutaneously the $P-R$ interval shortened to 0.16 second and the rate increased to $62 /$ minute. As further acceleration took place, however, 2:1 second-degree heart block appeared, with a ventricular rate of $40 /$ minute. The blood pressure fell to 80 $\mathrm{mm} \mathrm{Hg}$ systolic, the extremities became cold, and increasingly frequent ventricular extrasystoles were noted.

It was decided to perform emergency pacing, and as the risk of ventricular fibrillation seemed so high lignocaine $1 \mathrm{mg} / \mathrm{kg}$ body weight was infused intravenously in one minute, but had no effect after a further three minutes. Phenytoin, $250 \mathrm{mg}$ in five minutes, was then given intravenously in the supplied solvent. During this infusion the ectopic beats declined in frequency, the atrial rate slowed, with persistence of 2:1 heart block, and within seconds of the completion of the infusion the $P$ waves were seen on the E.C.G. monitor to disappear altogether, leaving a unifocal ventricular bradycardia of $12 /$ minute. The patient lost consciousness and blood pressure could not be recorded. Isoprenaline was infused to a dose of $200 \mu \mathrm{g}$, after which the idioventricular rhythm accelerated to $50 /$ minute and consciousness returned. Insertion of a ventricular-inhibited endocardial demand pacemaker was rapidly carried out via the left antecubital vein, and pacing at 2 volts (threshold 0.8 volt) continued at $80 /$ minute without competition from the $2: 1$ heart block that had by this time become reestablished. Thereafter the blood pressure remained above 100 $\mathrm{mm} \mathrm{Hg}$ systolic, there was no evidence of cardiac insufficiency, and sinus rhythm had returned by the sixth day, when the pacemaker was removed. The patient was discharged after three weeks and at the time of the six-month review was free of symptoms and back at work as a painter.

\section{Comment}

The development of heart block complicating inferior infarction and the satisfactory recovery resulting from the use of a

Department of Therapeutics, University of Aberdeen

ROBERT A. WOOD, B.SC., M.R.C.P.ED., Lecturer pacemaker is not unusual. Lignocaine is generally contraindicated in heart block and was given to this patient only when the decision to pace had been taken. Phenytoin, given at $\mathbf{5 0}$ $\mathrm{mg} / \mathrm{minute}$ for five minutes intravenously, caused sinoatrial arrest and greatly depressed the rate of discharge of the ectopic ventricular focus that had resisted lignocaine therapy.

The depressant effect of phenytoin on pacemaker tissue occurs at high dose or rapid rate of administration in the dog (Covino, Wright, and Charleson, 1955), and fatalities due to standstill have occurred in man when $250 \mathrm{mg}$ has been given in two minutes (Unger and Sklaroff, 1967), in two and a half minutes (Goldschlager and Karliner, 1967), and at an unknown rapid rate (Rosen, Lisak, and Rubin, 1967). Transient sinus bradycardia responding to atropine was reported (Conn, 1965 ) in a series when the drug was given at a rate of $250 \mathrm{mg}$ in one to three minutes, and one case of sinus arrest responded to a blow on the chest in a series in which a similar dose was given in 30 seconds to four minutes (Rosen et al., 1967). No sinoatrial depression was noted in a group of patients receiving $250 \mathrm{mg}$ in three to five minutes into the pulmonary artery (Conn, Kennedy, and Blackman, 1967) or in series of patients given $250 \mathrm{mg}$ in three to five minutes (Karliner, 1967), $125 \mathrm{mg}$ in two to five minutes (Mercer and Osborne, 1967), or $100 \mathrm{mg}$ at five-minute intervals (Bigger, Schmidt, and Kutt, 1968). It is especially interesting that complete sinoatrial arrest should have occurred within the recommended dosage level in a patient theoretically protected against this side effect by previous dosage with atropine. The increased tendency towards sinus arrest after acute inferior infarction may have been a contributory factor, but as it has been shown in the dog that phenytoin and procainamide have additive effects on pacemaker tissue (Helfant et al., 1967) a similar interaction might occur between phenytoin and lignocaine in man, and indeed was predicted (Damato, 1969).

Great caution should be exercised when phenytoin is given intravenously, especially when the subject has any susceptibility to sinus arrest or when a drug such as a local anaesthetic or a $\beta$ adrenergic blocking agent, with depressant effects on automatic tissue, has already been given. In such circumstances conventional dosage may be excessive. Atropine and isoprenaline are the theoretical antidotes to phenytoininduced sinoatrial arrest. In the case described isoprenaline proved to be very effective.

I wish to thank Professor A. G. Macgregor for permission to publish this account of a patient under his care.

\section{References}

Bigger, J. T., Schmidt, D. H., and Kutt, H. (1968). Circulation, 38, 363. Conn, R. D. (1965). New England fournal of Medicine, 272, 277.

Conn, R. D., Kennedy, J. W., and Blackman, J. R. (1967). American Heart fournal, 73, 500 .

Covino, B. G., Wright, R., and Charleson, D. A. (1955). American fournal of Physiology, 181, 54 .

Damato, A. N. (1969). Progress in Cardiovascular Diseases, 12, 1.

Goldschlager, A. W., and Karliner, J. S. (1967). American Heart fournal,

74, 410. A. Scherlag, B. J., and Damato, A. N. (1967). Circulation, 36,
Helfant, R. H., Schal, 108 .

Karliner, J. S. (1967). Diseases of the Chest, 51, 256.

Mercer, E. N., and Osborne, J. A. (1967). Annals of Internal Medicine, 67, 1084.

Rosen, M., Lisak, R., and Rubin, I. (1967). American fournal of Cardiology, 20, 674 .

Unger, A. H., and Sklaroff, H. J. (1967). Journal of the American Medical Association, 200, 159. 